\title{
Survey on the Use of Energy in Ovens for Baking Bread in North Central Nigeria
}

\author{
Adamu Cornelius Smah*, Ijabo Oga Joshua, Obetta Samuel Enyi \\ Department of Agricultural and Environmental Engineering, Federal University of Agriculture, Makurdi, Nigeria \\ Email address: \\ cornyadamu@gmail.com (A. C. Smah) \\ ${ }^{*}$ Corresponding author \\ To cite this article: \\ Adamu Cornelius Smah, Ijabo Oga Joshua, Obetta Samuel Enyi. Survey on the Use of Energy in Ovens for Baking Bread in North Central \\ Nigeria. International Journal of Energy and Power Engineering. Vol. 10, No. 3, 2021, pp. 50-56. doi: 10.11648/j.ijepe.20211003.11
}

Received: May 24, 2021; Accepted: June 4, 2021; Published: June 21, 2021

\begin{abstract}
Bread is a staple food prepared from flour and water, usually by baking. In Africa, bread is the most consumed food, but are not mostly baked according to standards. This investigation was aimed at finding out the use of different sources of energy, temperature, and time of baking in bakeries and to determine suitable empirical parameters for the construction of dual powered automated oven for baking bread. Some major bread consuming local governments were selected in the states of Benue and Nasarawa. Gboko, Otukpo and Makurdi were the local governments selected in Benue state where 10 questionnaires were administered in each local government by direct delivery. Lafia, Akwanga and Keffi local governments' areas were selected in Nasarawa State where 10 questionnaires were also served. they were retrieved after being filled by respective respondents and the data collected were analyzed using simple descriptive statistics of frequency, percentages and ANOVA. The mean temperature was estimated to be $179.38 \pm 19.90^{\circ} \mathrm{C}$ in Benue state and $153.13 \pm 19.90^{\circ} \mathrm{C}$ in Nasarawa State. The mean time of baking was found to be $29.06 \pm 19.90 \mathrm{~min}$ in Benue state and $27.50 \pm 1.12 \mathrm{~min}$ in Nasarawa state. The temperature and time in both states are not significantly different at $(\mathrm{p}<0.05)$. The energy sources in percentage in Benue state were estimated to be $70 \%, 3 \%, 7 \%, 17 \%, 3 \%$ and $0 \%$ for wood/charcoal, gas, electricity, electricity versus gas (separated), and dual powered of electricity and gas respectively. In Nasarawa state, the sources of energy were found to be $47 \%$, 30\%, 3\%, $13 \%, 7 \%$ and $0 \%$ for wood/charcoal, gas, electricity, electricity versus gas (separated), charcoal versus gas (separated) and dual powered of electricity and gas respectively. The mean cost of energy consumption in both states were estimated to be $\$ 8218.75 \pm 720.16$ and $\$ 4625.00 \pm 720$ in Benue and Nasarawa state and the cost of energy consumption are significantly different at $(\mathrm{P}<0.05)$ respectively. The results show that no bakery in both states uses dual automated oven for baking bread. A mean temperature of $166.26 \pm 19.90^{\circ} \mathrm{C}$ and mean time of $28.28 \pm 1.12$ minutes was established for North-Central Nigeria and could stand as a standard for the construction of dual automated oven for baking bread.
\end{abstract}

Keywords: Survey, Baking Bread, Energy Sources, Temperature and Time, Oven, North-Central

\section{Introduction}

Baking is process of cooking by dry heat; it is an essential way of preparing food from raw materials. It can be used in preparing breads, biscuits, cakes, pastries, pies, cookies and crackers [1]. Baking oven is a complex simultaneous heat and mass transfer equipment commonly applied in food industries. An oven can be simply described as a thermal insulated chamber used for the heating, baking, cooking, or drying of food substances [2]. During baking, the driving force of heat transfer is the temperature gradient while that of mass diffusion is concentration difference. However, they occur simultaneously and opposite direction within the food product from the outer part to the inner part of the food material. Heat is transferred much more effectively if the air is moving near the dough piece at a given temperature. It was reported that during baking the moisture diffusion in the food material occurs mainly by convection and conduction, less by radiation [3]. Hence, loss of moisture, reduction in product density, a change in surface colouration and a change of shape are been observed during baking. For effective baking, heat losses should be minimal. Hence many indigenous 
baking ovens, made from mud, are fired by wood [4]. The shortcomings of baking are: long baking time, nonhomogenous heat distribution and thermal energy losses which often results in increase of the cost of production and air pollution [4]. Ogunjobi and Ogunwole [5] reported in 2010 that increase in population, rapid urbanization, and changing food habits have resulted in the preference for ready to eat convenient foods such as bread, biscuits, and other baked products, despite the increase in their prices. Aborisade and Adewuyi [4] gave a report that it is unfortunate that many countries in Africa use the large-scale bakers which underutilizes the imported ovens, which are awfully expensive instead of small-scale or household bakers. Presently, irregular supply of electricity in some of these countries have rendered electric baking oven unproductive across all levels of operations. However, it is expected that electric power supply would improve. With the increasing availability of liquefied gas especially in Nigeria, there is a need to supplement the erratic power supply in cooking and baking operations. The development of an indigenous dual energy oven (gas and electric energy mode) to support baking in Nigeria and Africa is needful; this is to support the processing of food and its quality. Hence, this survey is aimed at determining the optimum parameters as a prelude to the use of dual powered automated rotary oven for baking bread in North Central Nigeria using Nasarawa and Benue State as a case study. Such data as the temperature generated from both gas and electric oven with the corresponding time of baking will be used as a guide to develop dual automated oven for baking bread

\section{Materials and Methods}

\subsection{Study Area}

The study area comprised of Benue and Nasarawa in the North Central region of the Nigeria as shown in figures 1 and 2. Benue state lies in latitudes $7^{\circ} 20^{\prime} \mathrm{N}, 8^{\circ} 45^{\prime}$ and longitudes $7.33^{\circ} \mathrm{N}, 8.75^{\circ} \mathrm{E}$ with a total land size of $34,059 \mathrm{~km}^{2}[6]$ and a population of $4,253,601$ [7]. Nasarawa State lies on latitude $8^{\circ} 32^{\prime} \mathrm{N}, 8^{\circ} 8^{\prime} \mathrm{E}$ and longitude $8^{\circ} 53^{\prime} \mathrm{N} 8.3^{\prime} \mathrm{N}$ [8] with a total land size of $28,735 \mathrm{~km}^{2}$ and a population of $2,679,433$ [7]. Three towns were selected from each state based on economic activities. The cities are the top three most populated cities in each state. Benue state comprised of Makurdi with the population of 509797, Gboko with 500,000 and Otukpo with 303,256 [7]. Nasarawa State comprised of Lafia with a population of 330,712, Akwanga has 113,430 and Keffi with 92664 [7]. Ten bakeries were selected from each town to administer the questionnaires; sixty questionnaires were distributed in all the six selected cities based on population of factories and rate of bread consumption.

\subsection{Data Collection}

Guided questionnaires were distributed to popular bakeries. They were filled by the respective heads of the bakeries and were all retrieved for further analyses.

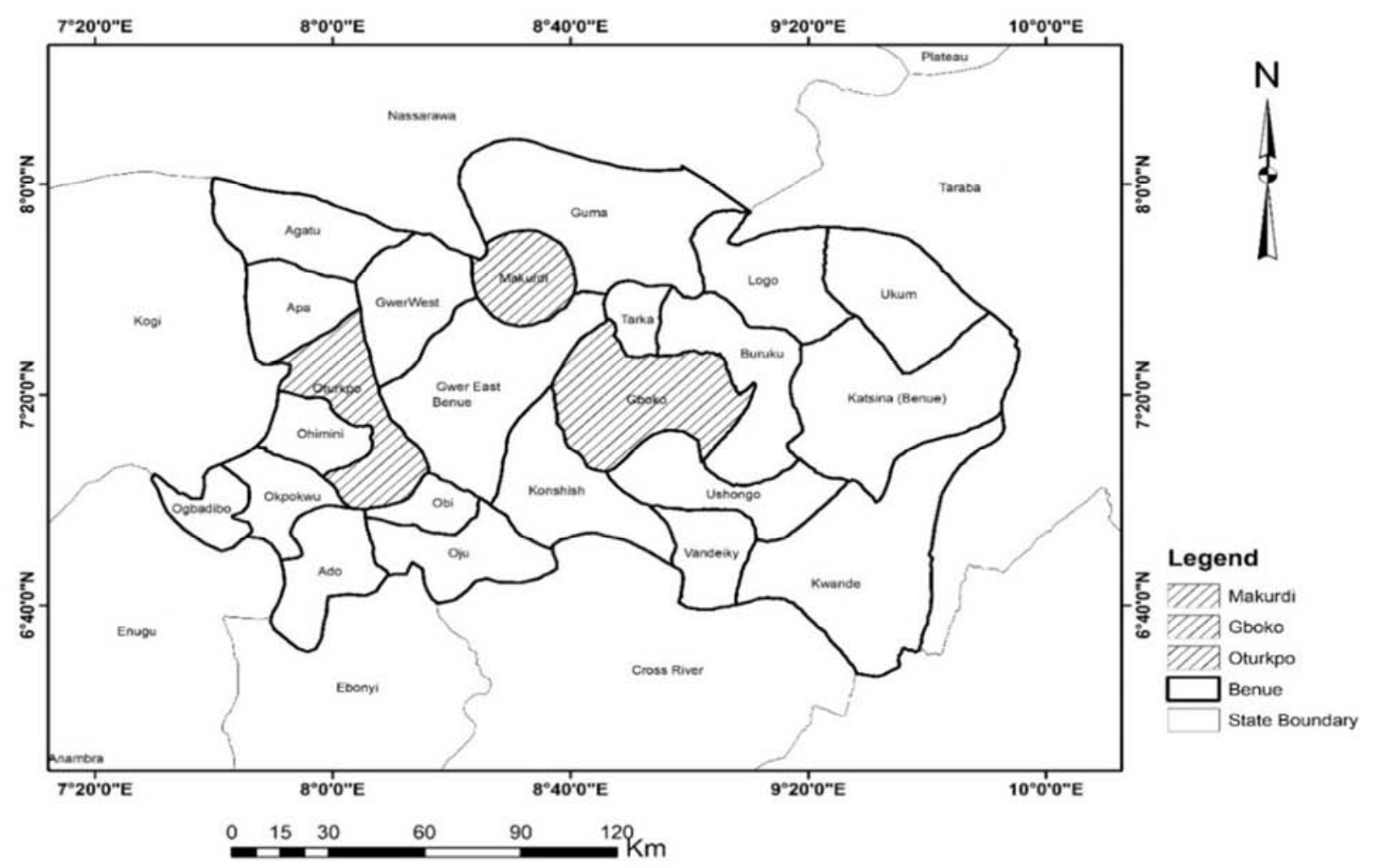

Figure 1. Map of Benue State showing the Study Area [7]. 
Table 1. List of visited Bread Bakeries in Benue State.

\begin{tabular}{|c|c|c|c|c|c|}
\hline $\mathbf{S} / \mathbf{N}$ & BAKERY & $\mathbf{S} / \mathbf{N}$ & BAKERY & $\mathbf{S} / \mathbf{N}$ & BAKERY \\
\hline & & 11 & Lucky star bakery & 22 & Ostrich bakery \\
\hline 1 & National daily Manners & 12 & Delight bakery & 23 & Steam fast \\
\hline 2 & Chinedu Company & 13 & Delightsome bakery & 24 & St. James bakery \\
\hline 3 & Chris Royal & 14 & Universal bakery & 25 & Adebayo bakery \\
\hline 4 & Triune bakery & 15 & Travelers' bakery & 26 & Top Choice bakery \\
\hline 5 & Normas bakery & 16 & Karama bakery & 27 & Goodbye Quality bakery \\
\hline 6 & Bisilad bakery & 17 & Texas bakery & 28 & Dexter \\
\hline 8 & Tikos bakery & 19 & Our Fathers bakery & 30 & St. Felix bread \\
\hline
\end{tabular}

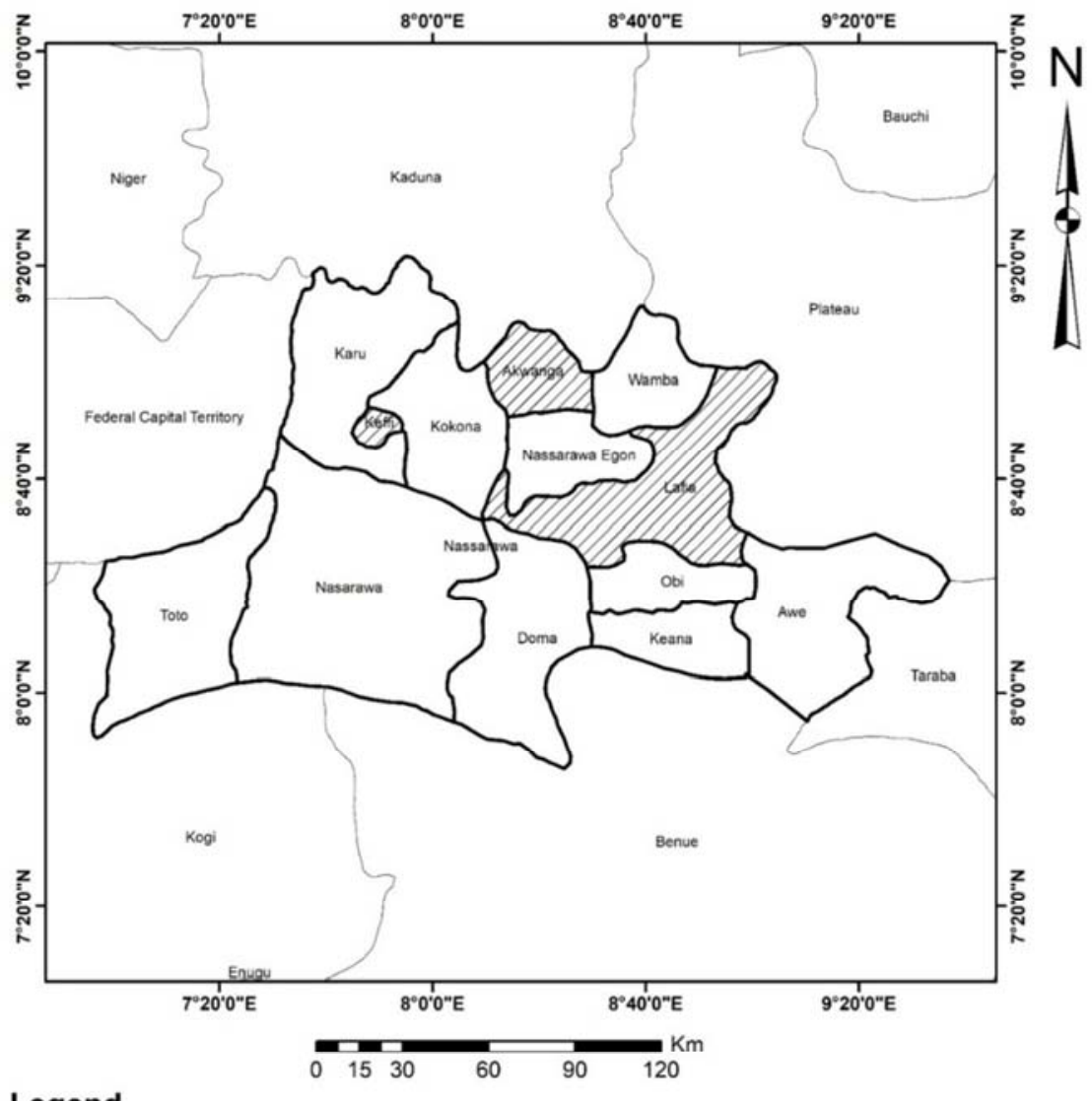

Legend

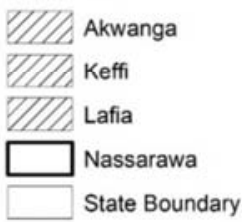

Figure 2. Map of Nasarawa state Showing the Study Areas [8].

Table 2. List of bread bakeries visited in Nasarawa State.

\begin{tabular}{llllll}
\hline S/N & BAKERY & S/N & BAKERY & S/N & BAKERY \\
\hline 1 & E-Three Special Bakery & 12 & Command bakery & 22 & Dadin Kowa bakery \\
2 & Favour Bakery & 13 & Musa bakery & 23 & Vertex \\
3 & First Land Bakery & 14 & Amy bakery & 24 & A. A Delicious bakery \\
4 & Divine Living Special bakery & 15 & Abdullahi bakery & 25 & Mikes bakery \\
5 & Romantic Bakery & 16 & Liyafa bakery & 26 & Ultimate bakery \\
6 & Lace & & & 27 & Nasara bread \\
7 & Oven Pride & 17 & Better Land bakery & 28 & Igwe E. bakery \\
8 & Lovers Family & 18 & Savannah bakery & 29 & Tantalizer Plc \\
9 & Easy Bite & 19 & God's Promise bakery & 30 & Ejidike bakery \\
10 & Royal Special Bakery & 20 & St. Woja bakery & & \\
11 & Happy Family bakery & 21 & Break Fast bakery & \\
\hline
\end{tabular}




\subsection{Procedure}

Questionnaires were retrieved and all the indices were graded for easy analysis. At 1 to 6 scale for the energy source i.e 1=Wood/Charcoal, 2= Gas, 3= Electricity, 4= Electricity and gas (Separate), 5= Charcoal and gas (separate) $6=$ Dual gas and Electricity (Automated). $7=$ No idea. The temperature of baking was graded to scale of 1 to 4 . Where $1=\left(51^{\circ} \mathrm{C}\right.$ $\left.150^{\circ} \mathrm{C}\right), 2=\left(151^{\circ} \mathrm{C}-250^{\circ} \mathrm{C}\right), 3=\left(251^{\circ} \mathrm{C}-350^{\circ} \mathrm{C}\right)$ and $4=$ No idea. The cost of baking per day was graded from 1 to 5 with 1

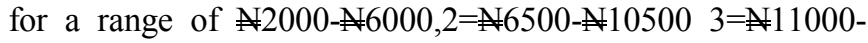
$\$ 15000,4=\$ 15,500-\$ 19,500,5=$ No idea. The time of baking was graded in 1 to 4 scale at $1=10-20 \mathrm{~min}, 2=21-30 \mathrm{~min}$, $3=31-60 \mathrm{~min}$, and $4=$ No idea. Each indices/index were calculated using the simple percentage and was later subjected an ANOVA SPSS Version 22 to determine the mean for cost, temperature, and time in the two states. The formula for determining each index is expressed as;

$$
\begin{gathered}
\text { Source of Energy }=\frac{\text { Number of bakeies for specific energy source }}{\text { Total number of bakeries }} \times 100 \\
\text { Temperature }=\frac{\text { Number of specific temperature range in bakeries }}{\text { Total number of bakeries }} \times 100 \text { (2) } \\
\text { Cost }=\frac{\text { Number of Specific cost range in a bakery }}{\text { Total number of bakeries }} \times 100 \\
\text { Time }=\frac{\text { Number of } \text { Specific time range in bakeries }}{\text { Total number of bakeries }} \times 100
\end{gathered}
$$

\section{Result}

Table 3. Energy Source.

\begin{tabular}{lllll}
\hline \multirow{2}{*}{ S/No. } & \multirow{2}{*}{ Energy } & Nasarawa & & Benue \\
\cline { 3 - 5 } & & No. of ovens & Percentage\% & No. of ovens \\
\hline 1 & Wood/Charcoal & 14 & 47 & 24 \\
2 & Gas & 9 & 30 & 1 \\
3 & Electricity & 1 & 3 & 2 \\
4 & Electricity\&Gas (Separated) & 4 & 13 & 5 \\
5 & Charcoal \& Gas (Separated) & 2 & 7 & 1 \\
6 & DualGas\&Electricity (Automated) & 0 & 0 & 0 \\
& TOTAL & 30 & 100 & 3 \\
\end{tabular}

${ }^{* *}$ N. I=No idea

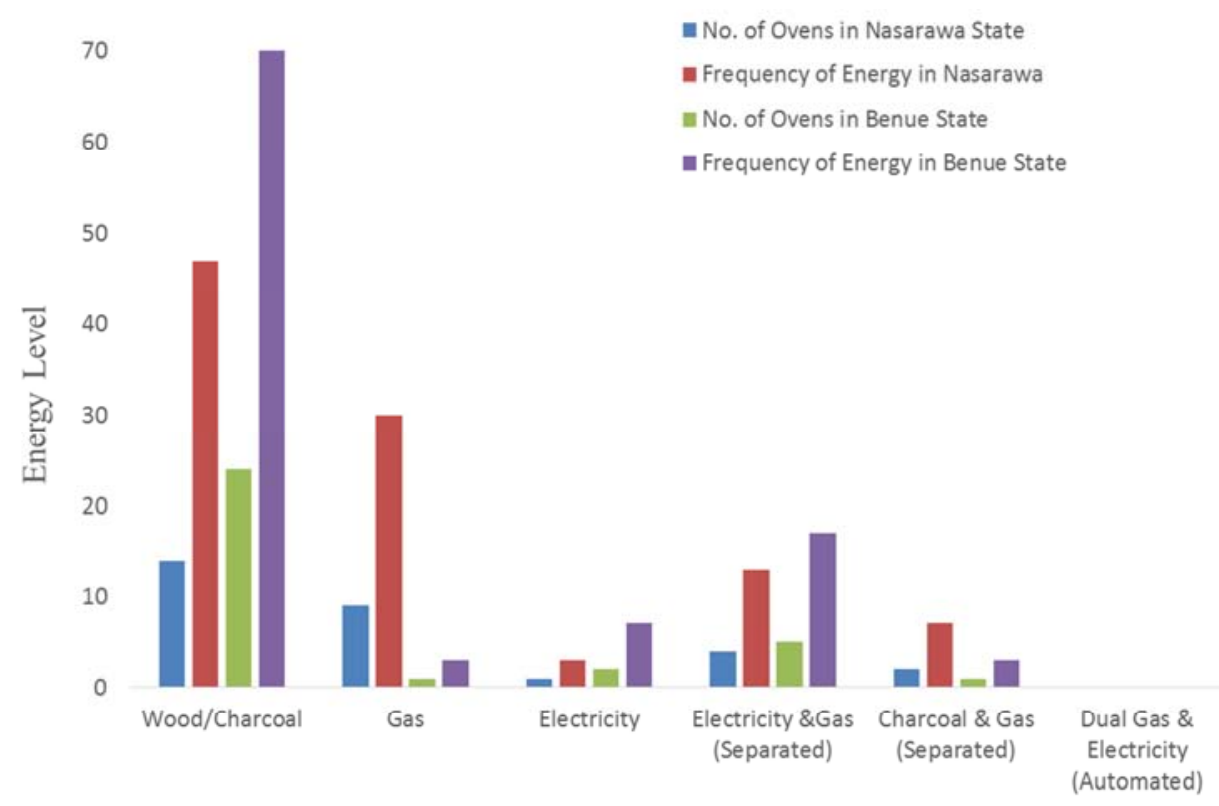

Source of Energy

Figure 3. A bar Chat showing the Energy Consumption in Bakeries.

From Table 3. The source of energy utilization in Benue state indicates that $70 \%$ of bakeries use charcoal for baking. This agreed with the investigation by Babalola in 2013[9] where he reported that $76.7 \%$ of the sampled household uses charcoal as energy source for cooking food. Seventeen percent $(17 \%)$ are powered by electricity and gas (Separated) in the same baking premises. Seven percent (7\%) of bakeries powered their bakeries only with electricity and 3\% are powered using gas. None of these bakeries in Benue State are powered by dual automated oven (gas and electricity) in one compartment. Nasarawa bakeries are estimated to rank in the order of be $47 \%$ that use firewood or charcoal to carryout 
bakery activities. Ogara reported in 2011[10] from an investigation conducted that $78.23 \%$ participants in Nasarawa state were involved in charcoal production for baking and cooking. Thirty percent $(30 \%)$ make use of gas, $13 \%$ use both electricity and gas at the same bakery but not in the same oven. Seven percentages (7\%) make use of charcoal and gas in the same premises of the bakery. Three (3\%) make use of electricity to carry out commercial bakery activities and none of these bakeries have dual gas and electricity oven that is automated in Nasarawa State. Heat directly or indirectly from the oven fired with wood for baking usually escape, by regularly opening and closing of the oven, this could affect workers health [11]. Amy [12] reported that one in three workers in bakeries powered by fossil fuel experience a hyperthermia, kidney injuries, muscle cramp and nausea.

Table 4. Temperature and Time of Baking. in Nasarwa and Benue State.

\begin{tabular}{|c|c|c|c|c|c|}
\hline & & Nasarawa & & Benue & \\
\hline $\mathbf{S} / \mathbf{N}$ & Temperature & No. of ovens & Percentage & No. of ovens Percentage & \\
\hline 1 & $50-150$ & 2 & 7 & 5 & 17 \\
\hline 2 & $151-250$ & 12 & 40 & 15 & 50 \\
\hline 3 & $251-350$ & 6 & 20 & 1 & 10 \\
\hline 4 & $\begin{array}{l}\text { N.I. } \\
\text { Time }\end{array}$ & 10 & 33 & 9 & 30 \\
\hline 1 & $10-20$ & 1 & 3 & 4 & 13 \\
\hline 2 & $21-30$ & 20 & 67 & 17 & 57 \\
\hline 3 & $31-60$ & 8 & 27 & 9 & 30 \\
\hline 4 & N.I. & 1 & 3 & 0 & 0 \\
\hline
\end{tabular}

$\mathrm{NI}=$ No idea

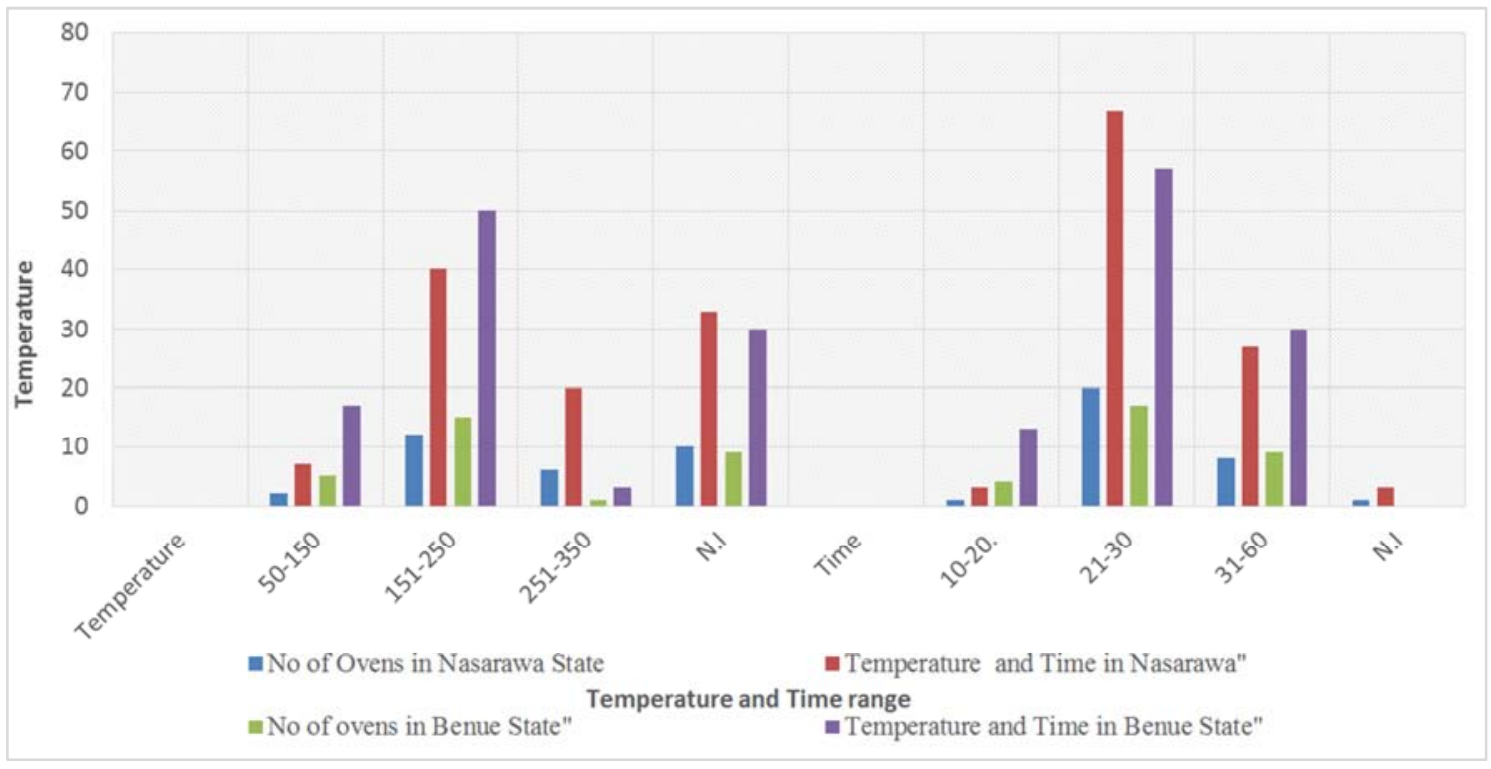

Figure 4. A bar Chart showing The Temperature and Time of Ovens.

Table 4 above show that in Benue State, the temperature of baking, $17 \%$ of bakeries have a range of $50-150^{\circ} \mathrm{C} .50 \%$ ranges between $151-250^{\circ} \mathrm{C} .3 \%$ in a range of $251-350^{\circ} \mathrm{C}$ and $30 \%$ have no idea of controlling their baking temperature in their bakeries. Nasarawa State temperature of baking was estimated to be $7 \%$ at range of $50-150^{\circ} \mathrm{C} .40 \%$ at a range of $151-250^{\circ} \mathrm{C} .20 \%$ ranges between $251-350^{\circ} \mathrm{C}$ and $33 \%$ of bakeries in the state have no idea of estimating their temperature. Javier et al., [13] reported that the optimum baking temperature is between $100-250^{\circ} \mathrm{C}$. From the above result, 30\% of bakers in Benue State and 33\% of bakers in Nasarawa State do not have idea of their baking temperature. This could probably affect the nutritional contents, quality, and texture of the bread. Shittu et al., [14] also stated that when temperature is not known, it will significantly affect the moisture contents, nutrients, colour and hardness of the bread in bakeries. This indicates that most bread consumed in these states do not meet nutritional standards. Table 4 above indicates that the time of baking in Benue state bakeries at range of 10-20minutes is $10 \%$, followed time range of $21-30$ minutes which is at $57 \%$. Range of $31-60$ minutes has $30 \%$. In Nasarawa state the time of baking ranges within 10-20 minutes at $3 \%$. Time range $21-30$ minutes at $67 \%$ in the state. At time range of $31-60$ minutes the percentage was $27 \%$ and $3 \%$ of bakeries have no idea on their baking time. The recommended time stated by Bojana et al. [15] for nutritional bread is between 20-40minutes where most Benue and Nasarawa bakers responded to have baked their bread within the time range. 
Table 5. Cost of Baking in Nasarawa and Benue.

\begin{tabular}{llllll}
\hline & & Nasarawa & & Benue & \\
\hline S/No. & Cost (N) Per day & No. of ovens & Percentage $\%$ & No. of ovens & Percentage\% \\
\hline 1 & $2,000-6,000$ & 13 & 43 & 22 & 73 \\
2 & $6,000-10,000$ & 5 & 17 & 3 & 10 \\
3 & $10,000-14,0000$ & 6 & 20 & 3 & 10 \\
4 & $14,000-18,000$ & 1 & 3 & 2 & 7 \\
5 & N.I & 5 & 17 & 0 & 0 \\
& TOTAL & 30 & 100 & 30 & 100 \\
\hline
\end{tabular}

N.I=No idea

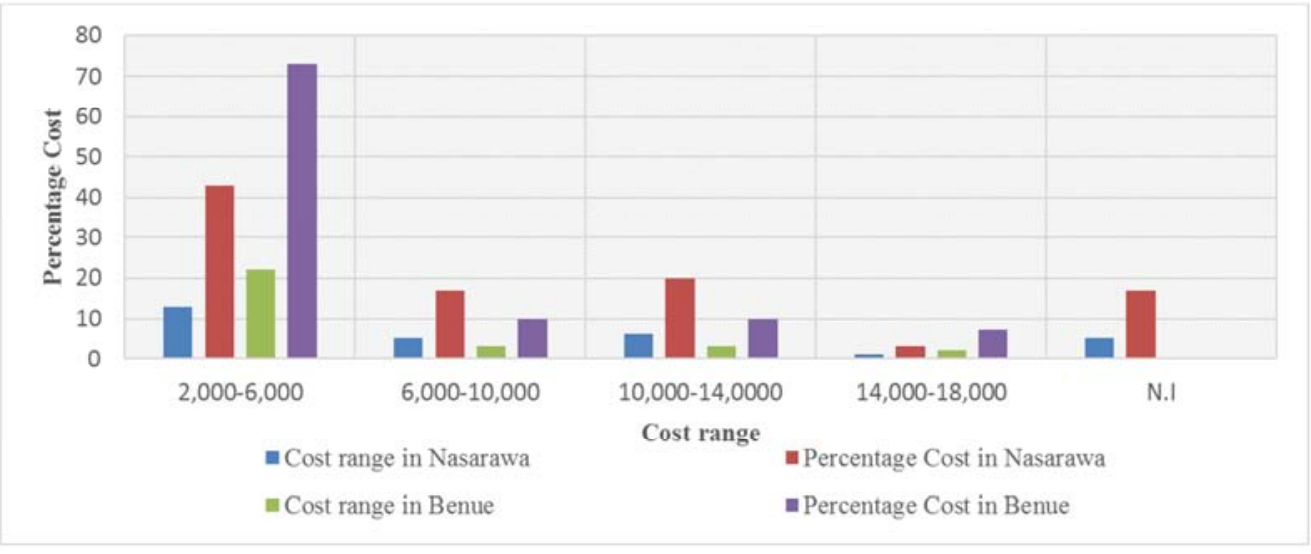

Figure 5. A bar showing the Level of Energy Consumption.

Table 5 above shows that $73 \%$ of bakeries in Benue State has cost of energy consumption range of $\$ 2000$ - $\$ 6000$ for charcoal/wood per day in Benue state. Ten percent $(10 \%)$ of bakeries have cost of energy consumption within $¥ 6000$ $\$ 10,000$ and $\$ 10,000$ - $\$ 14,000$ and these bakeries are using gas or electricity for baking, respectively. Seven percent (7\%) of bakeries or ovens consumption cost is between 14000 $\$ 18000$ also uses gas and electricity for baking. None of all these bakeries in Benue state makes use of dual automated ovens in their bakeries in Benue state. In Nasarawa state, $43 \%$ of bakeries have cost of energy consumption range of $\$ 2000$ $\$ 6000$, this indicates that most bakeries that fall in this price range are of fossil fuel energy source. Seventeen percent (17\%) have cost of consumption range of $\$ 6000-\$ 10000$, it was found these bakeries are powered by electricity or gas. Twenty percent (20\%) have cost of consumption range of $10,000-\$ 14,000$ and most of these bakeries are making use of gas and electricity as energy source. $17 \%$ of bakeries in Nasarawa state do not know the estimate of their baking costs. Earnest [16] reported that high performance of bakery requires a structured energy management; the author further stated that when energy is professionally managed, it helps bread companies to keep cost down and stay competitive.

Table 6. ANOVA Table of Cost, Temperature and Time.

\begin{tabular}{llll}
\hline \multirow{2}{*}{ Variable } & Location & & \\
\cline { 2 - 3 } & Nasarawa Mean \pm SE & Benue Mean \pm SE & Significance \\
\hline Cost of Energy $(\AA)$ & $4625.00 \pm 720.16^{\mathrm{a}}$ & $8218.75 \pm 720.16^{\mathrm{b}}$ & $* *$ \\
Temperature $\left({ }^{\circ} \mathrm{C}\right)$ & $153.13 \pm 19.90^{\mathrm{a}}$ & $179.38 \pm 19.90^{\mathrm{a}}$ & $\mathrm{NS}$ \\
Time (minutes) & $27.50 \pm 1.12^{\mathrm{a}}$ & $29.06 \pm 1.12^{\mathrm{a}}$ & $\mathrm{NS}$ \\
\hline
\end{tabular}

${ }^{\mathrm{ab}}$ Means on the same row bearing different superscripts are significantly different $(\mathrm{P}<0.05)$

** Significant at $95 \%$

NS-Not significant

SE-Standard error of mean

Table 6 shows that the mean cost of energy consumption in a day is significantly different. Benue and Nasarawa State are having a mean of $\$ 8218.75 \pm 720.16$ and $\$ 4625.00 \pm 720.16$ respectively. Benue State has the maximum energy consumption, which is almost twice the energy consumption of Nasarawa state as shown in Table 6. The mean temperature and time are not significantly different $153.13 \pm 19.90^{\circ} \mathrm{C}$ and $179.38 \pm 19.90^{\circ} \mathrm{C}$ at time of $27.50 \pm 1.12 \mathrm{~min}$ and $29.06 \pm 1.12 \mathrm{~min}$ in Nasarawa and Benue state, respectively. The temperature and time are within the acceptable range for baking of $100-250^{\circ} \mathrm{C}$ and $25-40$ minutes according to Javier et al., and Bojana et al, respectively.

\section{Challenges}

The following five challenges were encountered during the investigation and need be taken up by the statutory bodies.

a) Many bakeries visited refused to disclose any 
information as regarding their bakeries.

b) Some bakeries have no signposts or names of their company and some are at hidden locations

c) Many bakeries are not registered with National Agency for Food and Drug Administration and Control

d) The weight of bread in bakeries visited varies a lot and, so it was difficult to determine a specific or range of weights for analysis.

e) The sanitary conditions for most bakeries are extremely poor

\section{Conclusion}

The aim of this investigation was to find out the cost of energy, temperature, and time involved in bakeries for baking bread in the north central Nigeria and to find out if dual powered automated (Gas and electrical) bread baking is in use in the North Central Nigeria. From investigation it is advisable that energy management should be prioritized in the region for effective baking. A universal standard average temperature of $166.26 \pm 19.90^{\circ} \mathrm{C}$ and a Standard average time of $28.28 \pm 1.12$ minutes should be established. Investigation also revealed that there are some bakeries that have electrical baking oven but are not automated and some have gas oven and not automated. Having estimated the time of baking, and the temperature range from the survey, these ideas have been a standard in developing an automated bread baking oven having electricity as a major source of energy and gas as a backup energy for baking bread.

\section{Recommendations}

Dual powered automated oven should be researched and developed to the point of usage in our homes and industries; it should be used in bakeries to enable the production of healthy and nutritious breads for consumption in Nigeria.

The cost of energy consumption and energy utilization should be emphasized to bakeries in the region, especially Benue State to reduce the energy use throughout bakery operations.

National Agency for Food and Drug Administration and Control and Standard Organization of Nigeria should ensure proper monitoring of bread companies to control quality and standards.

Sensitization on the importance of accurate temperature and time should be emphasized by State Ministry of Commerce and Industry in other to carry out accurate baking.

Government should utilize the natural gas in the country by connecting pipelines to households and industries to enable them carry out baking, thereby reducing the use of woods/charcoals which cause deforestation

\section{References}

[1] Armando Manhiça, Fabião/ Lucas, Carlos/ Richards, Tobias (2012): Wood consumption and analysis of the bread baking process in wood-fired bakery oven. Applied Thermal Engineering, Volume 47,5 December 2012, P. 63-72.
[2] Komlaga G. A, Glover-Amengor M., Dziedzoave N. T. Hagan L. L., (2012). Consumer acceptability of wheat cassava composite bread, World Rur. Observatory, p. 78-81.

[3] Basil E., Blessant J (2014)" Development and Application of a Uniform Testing procedure for ovens, Pacific Gas and Electric" Company Department of Research and Development Report, 2014, 4, p. 10-25.

[4] Aborisade D. O., Adewuyi P. A. (2014). Evaluation of PID Tuning Methods on Direct Gas Fire Oven, International. Journal of Engineering Research and Applications, p. 1-9.

[5] Ogunjobi M. A., Ogunwole S. O. (2010). Physiochemical and sensory properties of cassava flour biscuits supplemented with cashew apple powder, Journal of Food Technology. p. 24-29.

[6] NBS (National Bureau of Statistics) (2016). www.google.com. Retrieved 15th August 2020.

[7] NPC (National Population Commission of Nigeria) (2016). www.wikipedia.com. Retrieved $12^{\text {th }}$ August 2020.

[8] NAGIS (Nasarawa Geographical Information System) (2012). www.wikipedia.com Retrieved $11^{\text {th }}$ July 2020.

[9] Babalola Folarin, Opii Egbe Emmanuel (2015) "Charcoal Versus other Domestic cooking fuel: Survey of factors influencing consumption in selected households of Benue state. Nigeria. International Journal of Organic Agriculture Research and Development Volume 6 (Sep. 2012).

[10] Ogara Janet Isaac (2011) "Preliminary Studies on Charcoal Production and Producers Knowledge of Environment Hazard in Nasarawa State.

[11] ILO (International Labour Organization) (2011) "Encyclopedia of Occupational Healtha nd Safety" wwww.google.com Retrieved 12th August, 2020.

[12] Amy North (2018) "Bakers at Risk for Heat Related Health Problem" British Bakers, 2018.

[13] Javier Martinez-Monzo, P. Garcia-Segoria, Jose Albors (2013) "Trends and Innovation in bread, bakery and Pastry. Journal of Culinary Science and Technology.

[14] Shittu. Taofeek A. O Raji and L. O Sani (2007) "Bread from Composite cassava wheat flour effect of baking time and temperature on some physical properties. Journal of Food Research International 40 (2007) 280-290.

[15] Bojana. M. Šarić*, Nataša M. Nedeljković, Olivera D. Šimurina, Mladenka V. Pestorić, Jovana J. Kos, Anamarija I. Mandić, Marijana B. Sakaĉ, Ljubiša Ć. Šarić, ĐorC̆eB. Psodorov, Aleksandra Ĉ. Mišan (2014) "The influence of baking time and temperature on characteristics of gluten free cookies enriched with blueberry pomade". Food and Feed Research. Journal of the Institute of Food Technology in Novi Sad.

[16] Earnest Orlando Lawrence (2012) "Energy efficiency improvement and cost savings opportunities for the bakery industry. US Department of Energy office of Scientific and Technical Information. United States Environmental Protection Agency 2012. 